\title{
How to interpret Methylation Sensitive Amplified Polymorphism (MSAP) profiles?
}

\author{
Jaroslav Fulneček ${ }^{*}$ and Aleš Kovařík
}

\begin{abstract}
Background: DNA methylation plays a key role in development, contributes to genome stability, and may also respond to external factors supporting adaptation and evolution. To connect different types of stimuli with particular biological processes, identifying genome regions with altered 5-methylcytosine distribution at a genome-wide scale is important. Many researchers are using the simple, reliable, and relatively inexpensive Methylation Sensitive Amplified Polymorphism (MSAP) method that is particularly useful in studies of epigenetic variation. However, electrophoretic patterns produced by the method are rather difficult to interpret, particularly when Mspl and Hpall isoschizomers are used because these enzymes are methylation-sensitive, and any C within the CCGG recognition motif can be methylated in plant DNA.

Results: Here, we evaluate MSAP patterns with respect to current knowledge of the enzyme activities and the level and distribution of 5-methylcytosine in plant and vertebrate genomes. We discuss potential caveats related to complex MSAP patterns and provide clues regarding how to interpret them. We further show that addition of combined Hpall + Mspl digestion would assist in the interpretation of the most controversial MSAP pattern represented by the signal in the Hpall but not in the Mspl profile.

Conclusions: We recommend modification of the MSAP protocol that definitely discerns between putative hemimethylated mCCGG and internal CmCGG sites. We believe that our view and the simple improvement will assist in correct MSAP data interpretation.
\end{abstract}

Keywords: MSAP, DNA methylation, Methylcytosine, Mspl, Hpall, Hemimethylated site, Data interpretation

\section{Background}

The DNA of most eukaryotic organisms contains 5methylcytosine $(\mathrm{mC})$ residues, which represent important epigenetic information involved in the regulation of gene expression during various developmental processes such as cell differentiation, imprinting, or X chromosome inactivation [1-3]. DNA methylation also contributes to genome stability by repressing harmful genetic elements [4]. The DNA methylation pattern may be changed by diet or stressful external conditions $[5,6]$. In plants, epialleles occurring naturally or after genetically/chemically induced epimutations may produce heritable phenotypic diversity supporting adaptation and evolution [7].

In a genome, only a fraction of cytosine residues is postreplicatively methylated by DNA (cytosine-5) methyltransferases [8]. The level of $\mathrm{mC}$ varies among individual species, and $\mathrm{mC}$ distribution along DNA is not uniform.

\footnotetext{
* Correspondence: fulnecek@ibp.cz

Institute of Biophysics, Academy of Sciences of the Czech Republic, v.vi.., Královopolská 135, Brno CZ-612 65, Czech Republic
}

Within an individual, the tissues or cell types differ in $\mathrm{mC}$ distribution. Repetitive sequences usually contain more $\mathrm{mC}$ than genic sequences [9]. Methylation of promoters leads to transcriptional inactivation of linked genes in most cases; the function of evolutionary conserved gene body methylation is still unknown $[10,11]$. Vertebrate DNA is predominantly methylated in CG dinucleotides [12-14]; however, in plant DNA, a cytosine in any sequence context can be methylated [15] with decreased frequency for CG, CHG, and $\mathrm{CHH}$ motifs ( $\mathrm{H}=\mathrm{A}$ or $\mathrm{T}$ or $\mathrm{C} ;[16])$.

To identify changes in the methylation of genomic DNA connected with biological processes or different types of treatments, a convenient method for $\mathrm{mC}$ detection should be used. Recently, several genome-wide methods were developed to analyze $\mathrm{mC}$ [17] based on bisulfite modification [16] or immunoprecipitation [18]. Because these methods are entirely dependent on detailed knowledge of the genome sequence, many scientists use Methylation Sensitive Amplified Polymorphism (MSAP), particularly in nonmodel organisms. The MSAP method based on di-

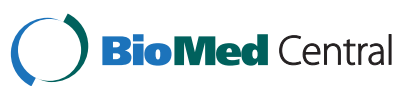


gestion with methylation-sensitive restriction endonucleases followed by amplification of restriction fragments is independent on the availability of genome sequence information and has been used frequently to analyze DNA methylation changes in plants and animals [19-21]. The MSAP procedure was first introduced by Reyna-Lopez and co-workers [22]. In their modification of the original amplified fragment length polymorphism protocol [23], frequent cutter $M s e I$ was replaced by methylation-sensitive $M s p I$ and HpaII restriction enzymes. However, the choice of these particular enzymes may lead to ambiguous interpretation of MSAP data, and some findings may be inconsistent with our current knowledge of mammalian and plant DNA methylation. Here, we reviewed 16 years of experience with the MSAP technique and attempted to explain the ambiguous characteristics of some restriction patterns considering the methylation sensitivities of restriction enzymes and known methylation frequencies of various sequence motifs in vertebrate and plant genomes. We present a modification of the MSAP protocol that would help to interpret the patterns of the most commonly used enzymes, MspI and HpaII.

\section{Results and discussion \\ Principle of MSAP}

In the original MSAP protocol [22], genomic DNA is divided into two parts, and each part is digested with EcoRI, which recognizes the GAATTC target site and is thought to be negligibly influenced by DNA cytosine methylation, and one of the methylation-sensitive $M s p \mathrm{I}$ or HpaII isoschizomers, which can both cleave CCGG sequences. MspI can cleave non-methylated CCGG sequences and hemi ( $\mathrm{mC}$ in one DNA strand only) or fully methylated CmCGG sequences but not hemi and fully methylated mCCGG and mCmCGG sequences [22,24]. HpaII is presumed to digest only non-methylated CCGG sequences and hemimethylated mCCGG sequences from all possible methylated CCGG variants [22,25]. The DNA samples digested with EcoRI and MspI or EcoRI and HpaII are ligated to two dsDNA adapters compatible with EcoRI- and MspI/HpaII-generated ends. Ligated fragments are preamplified using non-selective or pre-selective primers complementary to the adapters followed by amplification with a pair of selective primers (these are one- to three-base extended variants of nonselective or pre-selective primers at $3^{\prime}$ ends). Such amplification produces a reduced population of fragments that are separated in denaturing polyacrylamide gels. Visualization of fragments is usually accomplished by the introduction of a radioactively or fluorescentlylabeled primer during a selective amplification step. In the gel, each DNA sample is represented by two neighboring lanes of fragments resulting from EcoRI, MspIand EcoRI, HpaII-digested DNA (M and $\mathrm{H}$ lane, respectively). Thus, four $\mathrm{MH}$ fragment pattern variants "+ +, - -, + -, - +", referring to the presence $(+)$ or absence (-) of a fragment, can be observed for each position in the gel. The $(+,+)$ pattern (a fragment of definite length visualized in both the $M$ and $H$ lanes) is attributed to digestion by both enzymes at a non-methylated CCGG site. The (-, -) pattern indicates inhibition of digestion with both enzymes at a fully methylated mCmCGG site when another treated sample shows the presence of a fragment at that position. The (-, -) pattern may also represent a mutated site when genetically distinct samples are compared. The $(+,-)$ pattern representing a fragment of definite length visualized in the $\mathrm{M}$ but not in the $\mathrm{H}$ lane corresponds to digestion with $M s p$ I but not $H p a I I$ and refers to the presence of a CmCGG site. Finally, the $(-,+)$ pattern seems to be quite difficult to interpret, particularly in plant genomes where methylation occurs in both the CCG and CG motifs.

\section{Methylation sensitivity of restriction enzymes}

The interpretation of MSAP data is predominantly based on known restriction enzyme (RE) activities at recognition sequences modified by methylation. Data concerning the methylation sensitivity of REs and corresponding literature can be found at the website of The Restriction Enzyme Database (REBASE; http://rebase.neb.com; [26]). At REBASE, 18 different references were identified concerning $M s p I$ and/or HpaII enzyme activities at the recognition sequence containing $5-\mathrm{mC}$ residues (13 for MspI and 14 for HpaII; http://rebase.neb.com).

The CCGG recognition site can theoretically occur in 10 differentially methylated forms (Table 1), and not all of them were tested in MspI/HpaII activity assays. In addition, different methylated forms may provide identical $M s p I$ and HpaII digestion profiles, suggesting only limited ability of the MSAP method to detect all methylation changes at CCGG sites. As follows from the function of bacterial HpaII and MspI restriction-modification systems, CCGG sites should be resistant to digestion when the inner cytosines (for HpaII) or outer cytosines (for MspI) are methylated by cognate methyltransferases $[27,28]$. Simultaneously, postreplicatively generated sites methylated only at one DNA strand (termed hemimethylated) should also be resistant to digestion. It is known that MspI can digest HpaIImethylated sites (CmCGG) [29,30]; however, HpaII cannot digest MspI-methylated sites (mCCGG) [24,31]. Inconsistency has been found regarding the sensitivity of HpaII to methylation of the outer C (mCCGG) in the hemimethylated state. While earlier work reported cleavage of hemimethylated mCCGG sites with HpaII [25], other studies did not completely support such activity [24,31-33]. This discrepancy may be explained by the known slow HpaII nicking activity of the non-methylated DNA strand [24] possibly combining with impurity-driven nonspecific 
Table 1 Frequency, effect on cleavage and expected MSAP profile of ten different methylated forms of CCGG site

\begin{tabular}{|c|c|c|c|c|c|c|c|c|c|c|}
\hline Site & $\begin{array}{l}C \subset G G \\
G G C C\end{array}$ & $\begin{array}{l}{ }^{3} \mathrm{C}^{\mathrm{m}} \mathrm{CG} \mathrm{G} \\
\mathrm{G} \mathrm{G} \mathrm{C} \mathrm{C}\end{array}$ & $\begin{array}{l}\mathrm{C}^{\mathrm{m}} \mathrm{CG} \\
\mathrm{G} \mathrm{G}^{\mathrm{m}} \mathrm{CC}\end{array}$ & $\begin{array}{l}C^{\mathrm{m}} \mathrm{C} G \mathrm{G} \\
\mathrm{G} \mathrm{G}^{\mathrm{m}} \mathrm{C}^{\mathrm{m}} \mathrm{C}\end{array}$ & $\begin{array}{l}\mathrm{C}^{\mathrm{m}} \mathrm{CGG} \\
\mathrm{G} \mathrm{G} \mathrm{C}^{\mathrm{m}} \mathrm{C}\end{array}$ & $\begin{array}{c}{ }^{\mathrm{m}} \mathrm{C} \text { C G G } \\
\mathrm{G} \mathrm{G} \mathrm{C} \mathrm{C}\end{array}$ & $\begin{array}{l}{ }^{\mathrm{m}} \mathrm{C} \text { C G G } \\
\mathrm{G} \mathrm{G} \mathrm{C}^{\mathrm{m}} \mathrm{C}\end{array}$ & $\begin{array}{l}{ }^{\mathrm{m}} \mathrm{C} \text { C G G } \\
\mathrm{G} \mathrm{G}^{\mathrm{m}} \mathrm{C}^{\mathrm{m}} \mathrm{C}\end{array}$ & $\begin{array}{c}{ }^{\mathrm{m}} \mathrm{C}^{\mathrm{m}} \mathrm{CG} \mathrm{G} \\
\mathrm{G} \mathrm{GC} \mathrm{C}\end{array}$ & $\begin{array}{l}{ }^{{ }^{m}} C^{m} C G G \\
G^{m}{ }^{m} C^{m} C\end{array}$ \\
\hline$\overline{{ }^{1} \text { Frequency }}$ & Low & Low & High & High & ${ }^{9}$ Xlow & Xlow & Xlow & Xlow & Xlow & High \\
\hline Mspl & ${ }^{4}+$ & + & + & - & - &,$- n$ & - & - &,$- n$ & - \\
\hline Hpall & + & $6-8 n$ & - & - & - & $-{ }_{-1}^{8} \mathrm{~N}$ & - & - &,$- n$ & - \\
\hline${ }^{2} \mathrm{MH}$ pattern & ${ }^{5}(+,+)$ & $(+,-)$ & $(+,-)$ & ${ }^{7}(-,-)$ & $(-,-)$ & $(-,-)$ & $(-,-)$ & $(-,-)$ & $(-,-)$ & $(-,-)$ \\
\hline
\end{tabular}

${ }^{1}$ Frequency of theoretical methylated forms is estimated for plant genomes [16,37].

${ }^{2}$ MSAP profile pattern of a fragment with the site after digestion with Mspl (M) and Hpall $(\mathrm{H})$.

${ }^{3}\left({ }^{m} \mathrm{C}\right)$ represents 5 -methylcytosine residue.

${ }^{4}(+)$ sequence is cut.

${ }^{5}(+)$ a band is present.

${ }^{6}(-)$ sequence is not cut.

${ }^{7}(-)$ a band is absent.

${ }^{8} \mathrm{n}$ and $\mathrm{N}$ denote negligible and slow nicking of non-methylated strand, respectively.

${ }^{9}$ Xlow denotes extremely low.

nuclease activity in some samples. Such DNA degradation might be supported by the observed lower intensity of HpaII digestion products compared with non-digested or HpaII-methylated DNA templates [25]. Indeed, Korch and Hagblom found smearing of HpaII-digested products after longer incubation or a higher enzyme concentration and suggested contaminating unspecific nuclease(s) in all HpaII enzyme preparations they used [32]. The current view supports HpaII nicking activity of the non-methylated but not the methylated strand in hemimethylated mCCGG sequences [31]. However, there is continuing controversy that the specificity of the HpaII enzyme and its ability to digest hemimethylated mCCGG sequences may be dependent on the enzyme concentration and incubation time.

Although the EcoRI enzyme recognizing GAATTC is used as an enzyme that is not sensitive to methylation in MSAP, EcoRI did not digest GAATTmC sequences when cytosines at both strands are methylated [34,35]. Thus, EcoRI digestion may be inhibited by overlapping $\mathrm{C}$ methylation, indicating that not all changes in $\mathrm{MH}$ patterns always reflect changes in the methylation status of MspI/HpaII sites.

\section{Frequency of $\mathrm{mC}$ at CCGG sites in plant and vertebrate genomes}

Despite earlier reports regarding the high frequency of mCCG methylation in plant genomes, [36] the more recent data support the following frequencies: CmCGG > mCmCGG > > mCCGG [16,37] which is in accord with DNA methylation and demethylation studies in plants $[38,39]$. Although the expected frequency of MspI/HpaII sites is one per $256 \mathrm{bp}$, the exact spacing is highly variable depending mostly on the GC content of a particular chromosomal region. In regions with closely spaced CCGG sequences, the supposed internal CmCGG site(s) of the HpaII-EcoRI fragment would be digested by MspI, and the resulting shorter $M s p I-E c o R I$ fragment may be lost during selective amplification or may be too short for electrophoretic detection. This finding is consistent with the observation that most $(-,+) \mathrm{MH}$ type fragments are long, while most $(+,-) \mathrm{MH}$ type fragments are typically short [40]. If so, all isolated HpaII fragments of the $(-,+) \mathrm{MH}$ type should contain at least one additional internal CCGG site; indeed, this was reported for all such sequenced fragments [41]. Internal CCGG sequences were also identified in HpaII-specific fragments obtained from restriction landmark genome scanning of $A$. thaliana and rice, and their CmCGG methylation status was confirmed by Southern blot hybridization and/or by polymerase chain reaction (PCR) [42,43]. More evidence for the presence of internal CmCGG site(s) in the fragments of the $(-,+)$ MH type comes from MSAP analysis of seven swine tissues where approximately $26.2 \%$ and $25.7 \%$ of $\mathrm{MH}$ patterns were of the $(+,-)$ and $(-,+)$ type, respectively [21]. Considering that vertebrate genomes are methylated almost exclusively at CG sites and a nearly equal number of $(+,-)$ and $(-,+) \mathrm{MH}$ profiles, we may expect an identical origin of these two patterns; essentially, the occurrence of CmCGG sequences only. This presumption is certainly valid also for the other two vertebrate species analyzed by MSAP $[44,45]$.

\section{Hyper- and hypomethylation may not be easily} deciphered from MSAP patterns

Particularly for sequences with closely spaced MspI/ HpaII sites, up to half of the different MSAP pattern changes are ambiguous and potentially misinterpreted either at the level of methylation change or as a change in nucleotide sequence (Table 2). Considering a model DNA molecule with closely spaced CCGG sites occurring in five different methylation variants (Figure 1), variants 1-3 are found in both vertebrate and plant DNA while variants 4 and 5 are plant specific. First, we would expect amplification of the long fragment (L) due to the specific combination of preselective and selective primers. Variant 2 will show a $(-,+) \mathrm{MH}$ pattern (due to 
Table 2 Possible changes in MSAP MH profiles from Figure 1 and their interpretation

\section{Plants}

${ }^{1} \mathrm{MH} 1 \rightarrow \mathrm{MH} 2$

${ }^{2}(-,-) \rightarrow(+,+)$

$(-,-) \rightarrow(-,+)$

$(+,+) \rightarrow(-,-)$

$(+,+) \rightarrow(+,-)$

$(+,+) \rightarrow(-,+)$

$(+,-) \rightarrow(-,-)$

$(+,-) \rightarrow(+,+)$

$(+,-) \rightarrow(-,+)$

$(-,+) \rightarrow(-,-)$

$(-,+) \rightarrow(+,+)$

$(-,+) \rightarrow(+,-)$

\section{Vertebrates}

$\mathrm{MH} 1 \rightarrow \mathrm{MH} 2$

$(-,-) \rightarrow(+,+)$

$(-,-) \rightarrow(+,-)$

$(-,-) \rightarrow(-,+)$

$(+,+) \rightarrow(-,-)$

$(+,+) \rightarrow(+,-)$

$(+,+) \rightarrow(-,+)$

$(+,-) \rightarrow(-,-)$ methylation change

${ }^{3} \mathrm{~s}(\mathrm{mCmC} \rightarrow \mathrm{CC})$

${ }^{6} \mathrm{~s}(\mathrm{mCmC} \rightarrow \mathrm{CC})$ and $\mathrm{I}(\mathrm{CmC} \rightarrow \mathrm{CC})$

$\mathrm{s}(\mathrm{CC} \rightarrow \mathrm{mCmC})$

$\mathrm{s}(\mathrm{CmC} \rightarrow \mathrm{mCmC})$ and $\mathrm{I}(\mathrm{CmC} \rightarrow \mathrm{CC})$

$\mathrm{s}(\mathrm{mCmC} \rightarrow \mathrm{CmC})$

$\mathrm{s}(\mathrm{mCmC} \rightarrow \mathrm{CmC})$ and $\mathrm{I}(\mathrm{CC} \rightarrow \mathrm{CmC})$

$\mathrm{s}(\mathrm{mCmC} \rightarrow \mathrm{CmC})$ and $\mathrm{I}(\mathrm{CmC} \rightarrow \mathrm{CC})$

$\mathrm{s}(\mathrm{CmC} \rightarrow \mathrm{mCmC})$

$\mathrm{s}(\mathrm{CC} \rightarrow \mathrm{mCmC})$ and $\mathrm{I}(\mathrm{CC} \rightarrow \mathrm{CmC})$

$\mathrm{I}(\mathrm{CmC} \rightarrow \mathrm{CC})$

$\mathrm{s}(\mathrm{CC} \rightarrow \mathrm{CmC})$

$\mathrm{s}(\mathrm{CC} \rightarrow \mathrm{mCmC})$

$\mathrm{s}(\mathrm{CC} \rightarrow \mathrm{mCmC})$ and $\mathrm{I}(\mathrm{CC} \rightarrow \mathrm{CmC})$

$\mathrm{s}(\mathrm{mCmC} \rightarrow \mathrm{CC})$

$\mathrm{s}(\mathrm{mCmC} \rightarrow \mathrm{CmC})$ and $\mathrm{I}(\mathrm{CC} \rightarrow \mathrm{CmC})$

$\mathrm{s}(\mathrm{CC} \rightarrow \mathrm{CmC})$

$\mathrm{s}(\mathrm{CC} \rightarrow \mathrm{CmC})$ and $\mathrm{I}(\mathrm{CC} \rightarrow \mathrm{CmC})$

$\mathrm{I}(\mathrm{CC} \rightarrow \mathrm{CmC})$

$\mathrm{s}(\mathrm{mCmC} \rightarrow \mathrm{CmC})$

$\mathrm{s}(\mathrm{CmC} \rightarrow \mathrm{mCmC})$

$\mathrm{s}(\mathrm{CmC} \rightarrow \mathrm{mCmC})$ and $\mathrm{I}(\mathrm{CC} \rightarrow \mathrm{CmC})$

$\mathrm{s}(\mathrm{CmC} \rightarrow \mathrm{mCmC})$ and $\mathrm{I}(\mathrm{CmC} \rightarrow \mathrm{CC})$

$\mathrm{s}(\mathrm{mCmC} \rightarrow \mathrm{CmC})$

$\mathrm{s}(\mathrm{mCmC} \rightarrow \mathrm{CC})$ and $\mathrm{I}(\mathrm{CmC} \rightarrow \mathrm{CC})$

$\mathrm{s}(\mathrm{CmC} \rightarrow \mathrm{CC})$

$\mathrm{s}(\mathrm{CmC} \rightarrow \mathrm{CC})$ and $\mathrm{I}(\mathrm{CmC} \rightarrow \mathrm{CC})$

$\mathrm{l}(\mathrm{CmC} \rightarrow \mathrm{CC})$

$\mathrm{s}(\mathrm{mCmC} \rightarrow \mathrm{CmC})$ and $\mathrm{I}(\mathrm{CmC} \rightarrow \mathrm{CC})$

$\mathrm{s}(\mathrm{CmC} \rightarrow \mathrm{CC})$

$\mathrm{I}(\mathrm{CC} \rightarrow \mathrm{CmC})$

$\mathrm{s}(\mathrm{CmC} \rightarrow \mathrm{mCmC})$

$\mathrm{s}(\mathrm{CmC} \rightarrow \mathrm{mCmC})$ and $\mathrm{I}(\mathrm{CC} \rightarrow \mathrm{CmC})$
MSAP pattern (Figure 1)

${ }^{4} S^{5}(4 \rightarrow 1)$

$\mathrm{S}(5 \rightarrow 1)$

$\mathrm{L}(1 \rightarrow 4)$

$\mathrm{L}(3 \rightarrow 4)$

$\mathrm{S}(4 \rightarrow 2)$ or $\mathrm{S}(5 \rightarrow 3)$

$\mathrm{S}(4 \rightarrow 3)$

$S(5 \rightarrow 2)$

$L(3 \rightarrow 5)$

$L(1 \rightarrow 5)$

$\mathrm{L}(3 \rightarrow 2)$

$L(1 \rightarrow 2)$

$S(1 \rightarrow 4)$

$S(1 \rightarrow 5)$

$L(4 \rightarrow 1)$

$\llcorner(4 \rightarrow 3)$

$S(1 \rightarrow 2)$

$\mathrm{S}(1 \rightarrow 3)$

$\mathrm{L}(4 \rightarrow 5)$

$\mathrm{L}(4 \rightarrow 2)$

$\mathrm{S}(2 \rightarrow 4)$ or $\mathrm{S}(3 \rightarrow 5)$

$\mathrm{s}(2 \rightarrow 5)$

$\mathrm{S}(3 \rightarrow 4)$

$\mathrm{L}(5 \rightarrow 3)$

$\mathrm{L}(5 \rightarrow 1)$

$\mathrm{S}(2 \rightarrow 1)$

$\mathrm{S}(3 \rightarrow 1)$

$\mathrm{L}(5 \rightarrow 4)$

$\mathrm{L}(5 \rightarrow 2)$

$\mathrm{L}(2 \rightarrow 1)$

$\mathrm{L}(2 \rightarrow 3)$

$\mathrm{L}(2 \rightarrow 4)$

$\llcorner(2 \rightarrow 5)$

${ }^{7}$ interpretation

ambiguous

ambiguous

ambiguous

ambiguous

methylation

hypomethylation ambiguous

hypomethylation sequence change

MSAP pattern (Figure 1)

nterpretation

${ }^{8}$ new CCGG

mutation

new CmCGG

$\mathrm{L}(3 \rightarrow 2)$

mut. + met.

$\mathrm{I}(\mathrm{CmC} \rightarrow \mathrm{CC})$

$\mathrm{L}(1 \rightarrow 2)$

CCGG loss

hypomethylation

ambiguous

methylation

methylation

$\mathrm{s}(\mathrm{CC} \rightarrow \mathrm{CmC})$

$S(1 \rightarrow 2)$

mutation

methylation

new internal $\mathrm{CmCGG}$

CmCGG loss

mut. + met.

mutation 
Table 2 Possible changes in MSAP MH profiles from Figure 1 and their interpretation (Continued)

\begin{tabular}{|c|c|c|c|}
\hline \multirow[t]{2}{*}{$\overline{(+,-) \rightarrow(+,+)}$} & $\mathrm{s}(\mathrm{CmC} \rightarrow \mathrm{CC})$ & $S(2 \rightarrow 1)$ & \multirow[t]{2}{*}{ hypomethylation } \\
\hline & $\mathrm{s}(\mathrm{CmC} \rightarrow \mathrm{CC})$ and $\mathrm{I}(\mathrm{CmC} \rightarrow \mathrm{CC})$ & $S(3 \rightarrow 1)$ & \\
\hline$(+,-) \rightarrow(-,+)$ & $(\mathrm{CmC} \rightarrow \mathrm{CC})$ and new int. $\mathrm{CmCGG}$ & - & mutation \\
\hline \multirow[t]{2}{*}{$(-,+) \rightarrow(-,-)$} & $\mathrm{s}(\mathrm{CmC} \rightarrow \mathrm{CC})$ & $L(2 \rightarrow 1)$ & \multirow[t]{2}{*}{ ambiguous } \\
\hline & $\mathrm{I}(\mathrm{CC} \rightarrow \mathrm{CmC})$ & $\mathrm{L}(2 \rightarrow 3)$ & \\
\hline$(-,+) \rightarrow(+,+)$ & internal CmCGG loss & - & mutation \\
\hline$(-,+) \rightarrow(+,-)$ & $(\mathrm{CC} \rightarrow \mathrm{CmC})$ and int. $\mathrm{mCGG}$ loss & - & mutation \\
\hline
\end{tabular}

${ }^{1} \mathrm{MH} 1$ and $\mathrm{MH} 2$ represent the original (control) and a changed MSAP profile, respectively.

$2^{2}$ - and + in parentheses denote the absence and the presence of a band in Mspl (M) and Hpall (H) lanes.

${ }^{3} \mathrm{~s}$ and $\mathrm{I}$ indicate restriction sites in Figure 1 (the "methylation change" and "sequence change" columns).

${ }^{4} \mathrm{~S}$ and $\mathrm{L}$ indicate specific MSAP fragments (the "MSAP pattern column") according their lengths from Figure 1.

${ }^{5}$ The numbers in parenthesis correspond to the methylation states of the sequence and the MSAP profiles in Figure 1.

${ }^{6}$ Some MSAP profile changes are explained by two methylation changes (both $\mathrm{s}$ and I Mspl/Hpall sites).

${ }^{7}$ Interpretation for each $\mathrm{MH} 1 \rightarrow \mathrm{MH} 2$ profile change is noted in the interpretation column.

${ }^{8}$ Majority of possible MSAP profile changes in vertebrates are explained by gain or loss of the restriction site and therefore are expected to be very rare.

an internal CmCGG site) that will be changed either by hypomethylation (variant 1) or hypermethylation (variant 3) into a (-, -) MH pattern. A shift from the $(-,+)$ to the $(+,+) \mathrm{MH}$ pattern is not expected in vertebrate DNA samples; however, it may be quite frequent in plant samples (variant 4) and is caused by methylation of the outer cytosine in the internal CmCGG site. However, the most commonly used interpretation of the shift from the $(-,+)$ to $(+,+) \mathrm{MH}$ pattern is hypomethylation of a putative mCCGG site.

\section{A modified MSAP protocol improves problematic interpretation of the $(-,+)$ MH pattern}

As stated above, in plant genomes, the $(-,+)$ MH pattern seems to be particularly problematic because it may be interpreted as two different situations: (i) the cutting of the hemimethylated mCCGG sites with HpaII but not $M s p$ I and (ii) the presence of internal CmCGG site(s) between the cleaved distal CCGG and the EcoRI site (Figure 2). Correct interpretation of the $(-,+) \mathrm{MH}$ pattern is important for classification of methylation changes that may involve both hypermethylation and hypomethylation. Here we show that introduction of a "third" lane containing DNA digested with both $M s p \mathrm{I}$ and HpaII enzymes $(\mathrm{M}+\mathrm{H}$ lane) may be highly informative. The persistence of the " $\mathrm{H}$ only" band leading to the $(-,+,+)(\mathrm{M}, \mathrm{H}, \mathrm{M}+\mathrm{H}$, in this order $)$ pattern would support hemimethylation of the mCCGG. By contrast, loss of the "H only" band (-, +, -) indicates the presence of an internal CmCGG site. We decided to test this theoretical construct by analysis of control and hypomethylated tobacco DNA (Figure 3, Additional file 1: Figure S1). A typical $(-,+)$ MH pattern is shown in Figure 3 containing two HpaII fragments $(1,3)$ without corresponding peaks in the $M s p I$ lane. Neither fragment 1 nor fragment 3 was resistant to combined HpaII +
Msp I cleavage (-, +, -), indicating that fragments 1 and 3 contained two consecutive differentially methylated CCGG sites: one proximal to the EcoRI site methylated at CmCGG and one distal non-methylated CCGG site. The products of $M s p I$ digestion are not visualized probably because they are too short and/or are not amplified by the selective primers. In hypomethylated DNA, we observed a loss of fragments 1 and 3 after HpaII digestion (Figure 3, panel $\mathrm{H}_{-} \mathrm{h}$ ), further supporting the presence of internal CmCGG site(s) in the fragments. The only truly non-methylated fragment is fragment 2 that is visualized in the $H, M$ and $H+M$ lanes and indicates proper DNA digestion.

Dinucleotide "mCG only" methylation is localized in coding regions known to possess high GC content and a relatively high frequency of CCGG sites compared with the rest of the plant genome. Thus, the $(-,+,-)$ patterns are likely formed by fragments having their origin in coding regions. By contrast, the $(-,+,+)$ patterns, indicating mCCG methylation, would originate prevalently from repetitive non-coding regions because trinucleotide $\mathrm{mCHG}$ methylation is primarily localized to satellite repeats and transposons [46]. Thus, the proposed MSAP modification utilizing combined $\mathrm{M}+\mathrm{H}$ digestion may help to determine the genomic origin of methylated fragments. The mCmCGG sites, which are common in plant heterochromatin, will not be digested with either MspI or HpaII (-, -, - pattern). This may explain why heterochromatic sequences are usually underrepresented in eluted MSAP fragments.

Regarding vertebrate DNA, which is methylated almost exclusively in CG sequences, we infer that the $(-,+)$ MH pattern may not be interpreted as mCCGG methylation [21] but rather as internal CmCGG sites.

Because there is no entirely methylation-insensitive isoschizomer cutting at the CCGG motif, discrimination between methylation (epigenetic change) and mutation 


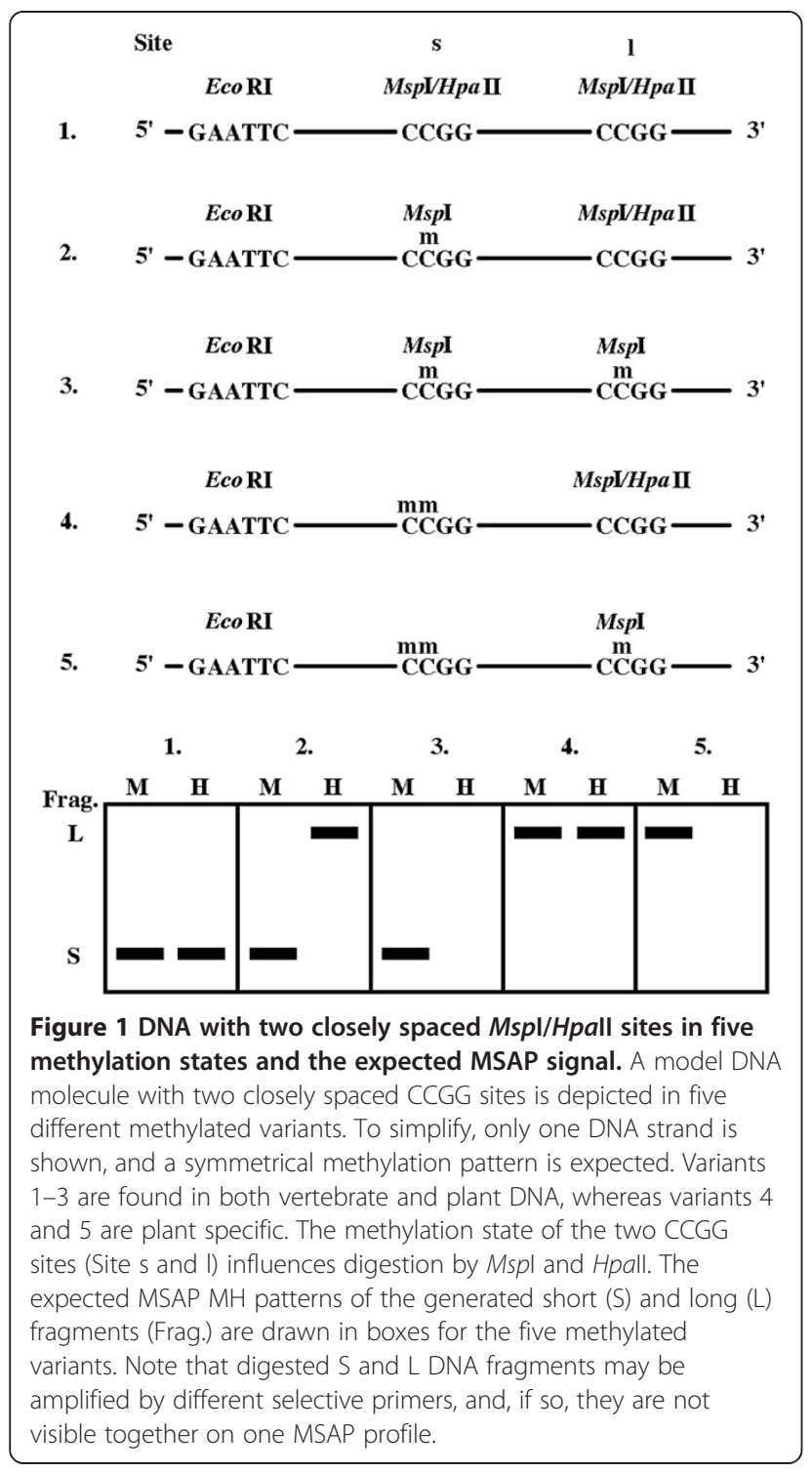

(genetic change) may be difficult, particularly among individuals of different genotypes. Therefore, employing other restriction sites may be an interesting option. Among others, Sau3AI (sensitive to methylation at GATmC sites), EcoT22I (ATGmCAT, [47]), NlaIII (mCATG), and ScrFI (CmCNGG) may be considered. For Sau3AI and NlaIII, methylation-insensitive MboI and $C v i \mathrm{AII}$ izoschizomers are available, respectively.

\section{Conclusions}

Clearly, the MSAP method is a reliable, inexpensive, and relatively simple genome-wide method for the identification of genome regions with putative changes in DNA cytosine methylation in response to environmental and developmental stimuli. While the interpretation of the $(+,-)$ and $(+,+) M s p I / H p a I I$ patterns is straightforward, the presence of an HpaII signal without a concomitant MspI signal $(-,+)$ is more ambiguous. In the latter case, we recommend modifying the MSAP protocol by including an additional lane in which the DNA sample is digested with a combination of both enzymes. Such improvement helps to distinguish between di- and trinucleotide methylation and between methylation in coding and noncoding areas of the plant genome.

\section{Methods}

\section{DNA samples}

We used DNA samples isolated from tobacco seedlings treated with 0,10 , and $100 \mu \mathrm{M}$ 9-(S)-(2,3-dihydroxypropyl)adenine (DHPA) and analyzed previously by MspI/HpaII digestion and Southern blot hybridization [48]. DHPA is a reversible competitive inhibitor of $S$-adenosylhomocysteine-hydrolase that elevates the intracellular SAH concentration [49]. SAH competes with $S$-adenosylmethionine (SAM), leading to inhibition of most SAM-dependent methyltransferases. In plants, DHPA treatment induces hypomethylation of CHG sites preferentially (CHG DNA methylation represents a metabolic bottleneck due to its dependence on histone methylation) and also hypomethylation of CG sites to some extent at elevated DHPA concentrations [48].

\section{MSAP procedure}

The MSAP procedure was performed in two technical replicates starting from the same DNA sample. DNA $(1 \mu \mathrm{g})$ was digested in NEB buffer 1 with $10 \mathrm{U}$ of HpaII (NEB) in

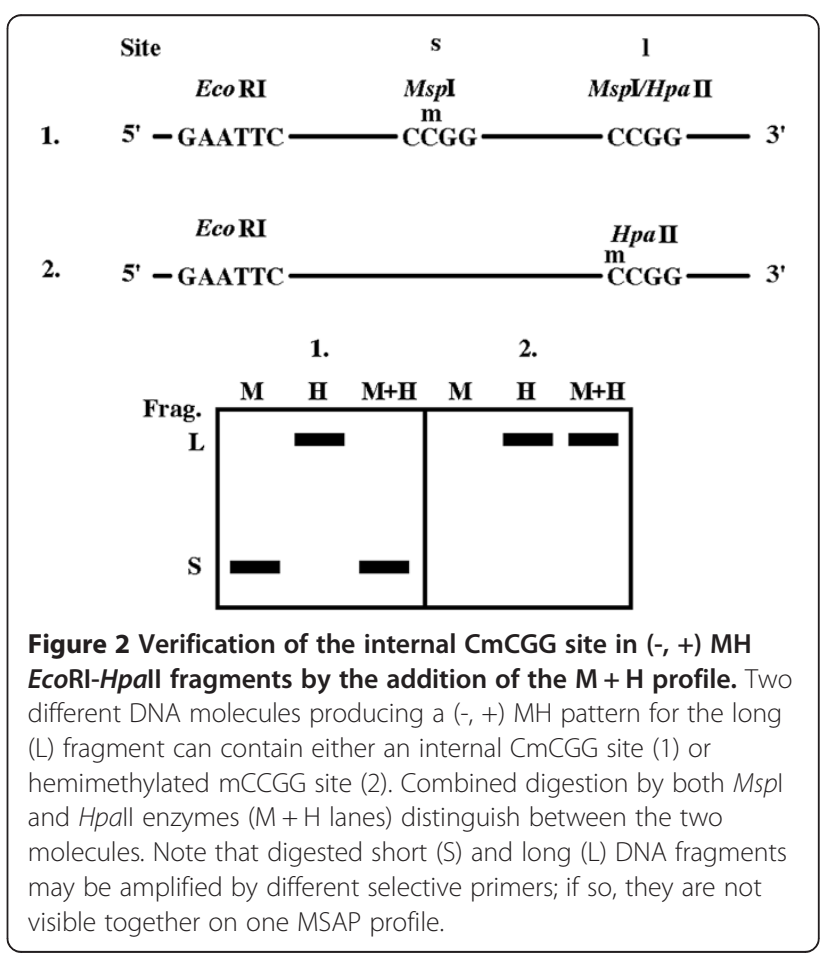




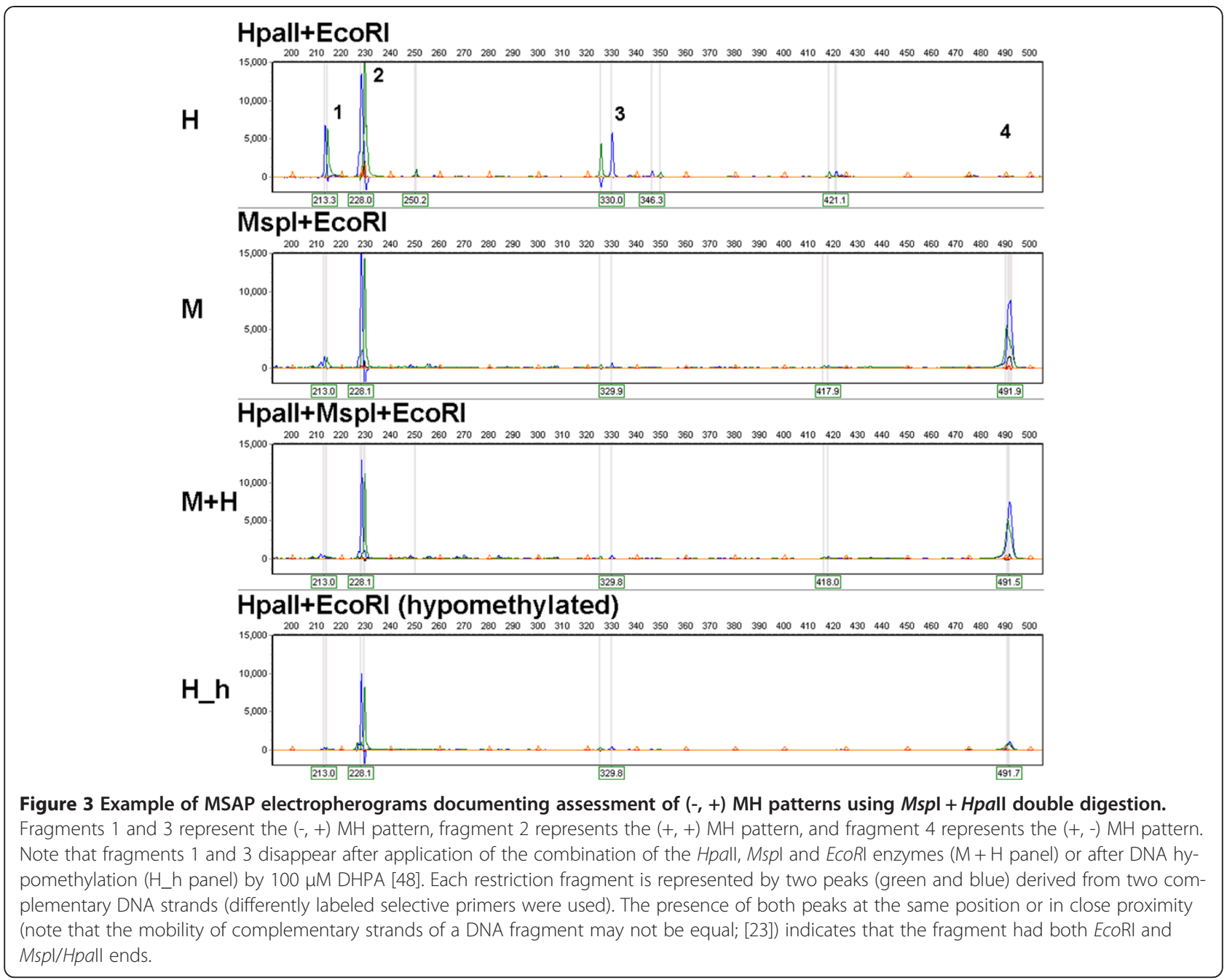

a $20-\mu \mathrm{l}$ reaction volume for 3 hours at $37^{\circ} \mathrm{C}$. Ten microliters of the reaction mixture was transferred to $10 \mu \mathrm{l}$ of NEB 2 buffer with $5 \mathrm{U}$ of $M s p \mathrm{I}$ (NEB) and incubated for 3 hours at $37^{\circ} \mathrm{C}$. Simultaneously, $0.5 \mu \mathrm{g}$ of the same original DNA sample was incubated in NEB 2 buffer with $5 \mathrm{U}$ of $M s p \mathrm{I}$ (NEB) in a 10- $\mu \mathrm{l}$ reaction volume for 3 hours at $37^{\circ} \mathrm{C}$. Next, $10 \mu \mathrm{l}$ of EcoRI buffer (NEB) with $5 \mathrm{U}$ of EcoRI (NEB) were added to $10-\mu \mathrm{l}$ reactions (HpaII and MspI digestions) and $5 \mu \mathrm{l}$ of $2.5 \times E c o$ RI buffer (NEB) with $5 \mathrm{U}$ of EcoRI (NEB) were added to a $20-\mu \mathrm{l} H p a \mathrm{II}+M s p \mathrm{I}$ reaction volume followed by incubation for an additional 1.5 hours at $37^{\circ} \mathrm{C}$. EcoRI_ADAPTER1(F) 5' -CTCGTAGACTGCGTACC-3' $(10 \mu \mathrm{M}) /$ EcoRI_ADAPTER2(R) 5'-AATTGGTACGCAGT CTAC-3' $(10 \mu \mathrm{M})$ and HpaII/MspI_ADAPTER1(F) 5'GATCATGAGTCCTGCT-3' $(100 \mu \mathrm{M}) / \mathrm{HpaII} / \mathrm{Msp} \mathrm{I}$-ADAPTER2(R) 5'-CGAGCAGGACTCATGA-3' (100 $\mu \mathrm{M})$ were used to prepare $5 \mu \mathrm{M}$ of EcoRI and $50 \mu \mathrm{M}$ of $\mathrm{MspI} /$ HpaII adapters, respectively, by mixing appropriate oligonucleotides and incubating at $98^{\circ} \mathrm{C}$ for $5 \mathrm{~min}$ followed by slow cooling in a polystyrene box (for approximately
6 hours). Six microliters of digested DNA samples was added to $3.75 \mu \mathrm{l}$ of mix comprising $1 \mu \mathrm{l}$ of $5 \mu \mathrm{M}$ EcoRI adapter ( $5 \mathrm{pmol}$ ), $1 \mu \mathrm{l}$ of $50 \mu \mathrm{M} \mathrm{MspI/HpaII}$ adapter (50 pmol), $1 \mu \mathrm{l}$ of fresh $10 \times$ T4 DNA ligase buffer, and $0.75 \mu \mathrm{l}$ of sterile redistilled water. After mixing and heating to $37^{\circ} \mathrm{C}, 0.25 \mu \mathrm{l}$ of T4 DNA ligase (100 U, NEB) was added, and the mix was incubated at $37^{\circ} \mathrm{C}$ for 3 hours followed by incubation at $20^{\circ} \mathrm{C}$ overnight. Non-ligated adapters were removed, and ligated DNA was purified using the NucleoSpin Gel and PCR Clean-up Kit (Macherey-Nagel). DNAs were eluted in $2 \times 10 \mu \mathrm{l}$ of $5 \mathrm{mM}$ Tris- $\mathrm{Cl}(\mathrm{pH} 8)$, and $3 \mu \mathrm{l}$ was used in $10-\mu \mathrm{l}$ preselective amplification reactions with EcoRI_A 5'-GACTGCGTACCAATTCA-3' and HpaII/ MspI_T 5'-ATGAGTCCTGCTCGGT-3' primers at 200 $\mathrm{nM}$ concentration each. In addition, the preselective reactions contain DynazymeII buffer, $125 \mu \mathrm{M}$ dNTPs, and $0.5 \mathrm{U}$ of DynazymeII DNA Polymerase (Thermo Scientific). The conditions of the preselective amplification were as follows: $72^{\circ} \mathrm{C}$ for $5 \mathrm{~min}, 94^{\circ} \mathrm{C}$ for $3 \mathrm{~min}$ followed by 30 cycles of $94^{\circ} \mathrm{C}$ for $30 \mathrm{~s}, 56^{\circ} \mathrm{C}$ for $30 \mathrm{~s}$, and $72^{\circ} \mathrm{C}$ for $2 \mathrm{~min}$. A final 
step at $60^{\circ} \mathrm{C}$ for $10 \mathrm{~min}$ was also added. Five microliters of preselective products was checked by electrophoresis in $2 \%$ agarose gels (visible as a smear from 100 to $1000 \mathrm{bp}$ ) and the remaining $5 \mu \mathrm{l}$ was diluted by adding $50 \mu \mathrm{l}$ of redistilled water. The diluted preselective product $(2.5 \mu \mathrm{l})$ was amplified using fluorescently labeled EcoRI_ACT[HEX] (green peaks in Figure 3 and Additional file 1: Figure S1) and labeled HpaII/MspI_TTC[6-FAM] (blue peaks in Figure 3) or HpaII/MspI_TAG (Additional file 1: Figure S1) selective primers (200 $\mathrm{nM}$ each) in a $12.5-\mu \mathrm{l}$ total reaction volume containing KAPA buffer B, $125 \mu \mathrm{M}$ dNTPs, and $0.5 \mathrm{U}$ of KAPA Taq DNA Polymerase (KAPA Biosystems). The conditions of the selective amplification were as follows: $94^{\circ} \mathrm{C}$ for $3 \mathrm{~min}, 13 \mathrm{cycles}$ of $94^{\circ} \mathrm{C}$ for $30 \mathrm{~s}, 65^{\circ} \mathrm{C}$ for $30 \mathrm{~s}$ reduced by $0.7^{\circ} \mathrm{C}$ per cycle, and $72^{\circ} \mathrm{C}$ for 2 min followed by 24 cycles of $94^{\circ} \mathrm{C}$ for $30 \mathrm{~s}, 56^{\circ} \mathrm{C}$ for $30 \mathrm{~s}$, and $72^{\circ} \mathrm{C}$ for $2 \mathrm{~min}$. A final step at $72^{\circ} \mathrm{C}$ for $10 \mathrm{~min}$ was also added. The product of selective amplification $(5 \mu \mathrm{l})$ was checked by $2 \%$ agarose gel electrophoresis. Next, $1.5 \mu \mathrm{l}$ of the selective amplification product was added to a mix of $10 \mu \mathrm{l}$ of deionized formamide for capillary electrophoresis (Genomac) and $0.3 \mu \mathrm{l}$ of GMC GT500-L DNA standard (Genomac) that is fluorescently labeled with LIZ dye (orange peaks in Figure 3 and Additional file 1: Figure S1). DNA was denaturated by heating at $98^{\circ} \mathrm{C}$ for $3 \mathrm{~min}$ followed by cooling on ice. Denatured DNA was separated using the fragment analysis option in the ABI Prism 3100 Genetic Analyzer. The obtained electropherograms were aligned according the signal of the DNA standard, analyzed and visualized using GeneMarker version 1.80 (SoftGenetics).

\section{Additional file}

Additional file 1: Figure S1. MSAP analysis of DNA samples isolated from tobacco seedlings treated with $0 \mu \mathrm{M}$ (DHPA 0), $10 \mu \mathrm{M}$ (DHPA 10) and $100 \mu \mathrm{M}$ (DHPA 100) 9-(S)-(2,3-dihydroxypropyl)-adenine (DHPA).

\section{Authors' contributions}

JF and AK designed the study, JF performed the experiments. JF and AK analyzed and interpreted the data as well as drafted the manuscript. Both authors read and approved the final manuscript.

\footnotetext{
Acknowledgements

This work was supported by the Czech Science Foundation (P501/12/G090, 13-10057S, 206/09/1751) and the Academy of Sciences of the Czech Republic (RVO68081707). The authors thank Dr. Bohuslav Janoušek and Ing. Vojtěch Hudzieczek for providing the EcoRI adapters, preselective primer, and fluorescently labeled primer, as well as for the valuable suggestions concerning fragment analysis. The authors also thank Dr. Jiři Široký for technical advice concerning fragmentation analysis (ABI Prism Genetic Analyzer) and providing a trial version of GeneMarker software.
}

Received: 30 July 2013 Accepted: 10 December 2013

Published: 6 January 2014

\section{References}

1. Rai K, Jafri IF, Chidester S, James SR, Karpf AR, Cairns BR, Jones DA: Dnmt3 and G9a cooperate for tissue-specific development in zebrafish. J Biol Chem 2010, 285(6):4110-4121.

2. Renfree MB, Suzuki S, Kaneko-Ishino T: The origin and evolution of genomic imprinting and viviparity in mammals. Philos Trans $R$ Soc Lond B Biol Sci 2013, 368(1609):20120151.

3. Sharp AJ, Stathaki E, Migliavacca E, Brahmachary M, Montgomery SB, Dupre $Y$, Antonarakis SE: DNA methylation profiles of human active and inactive X chromosomes. Genome Res 2011, 21(10):1592-1600.

4. Yoder JA, Walsh CP, Bestor TH: Cytosine methylation and the ecology of intragenomic parasites. Trends Genet 1997, 13(8):335-340.

5. Lim U, Song MA: Dietary and lifestyle factors of DNA methylation. Methods Mol Biol 2012, 863:359-376.

6. Solis MT, Rodriguez-Serrano M, Meijon M, Canal MJ, Cifuentes A, Risueno MC, Testillano PS: DNA methylation dynamics and MET1a-like gene expression changes during stress-induced pollen reprogramming to embryogenesis. J Exp Bot 2012, 63(18):6431-6444.

7. Durand S, Bouche N, Perez Strand E, Loudet O, Camilleri C: Rapid establishment of genetic incompatibility through natural epigenetic variation. Curr Biol 2012, 22(4):326-331.

8. Law JA, Jacobsen SE: Establishing, maintaining and modifying DNA methylation patterns in plants and animals. Nature rev 2010, 11(3):204-220.

9. Saze $H$, Kakutani T: Differentiation of epigenetic modifications between transposons and genes. Curr Opin Plant Biol 2011, 14(1):81-87.

10. Lunerova-Bedrichova J, Bleys A, Fojtova M, Khaitova L, Depicker A, Kovarik A: Trans-generation inheritance of methylation patterns in a tobacco transgene following a post-transcriptional silencing event. Plant J 2008, 54(6):1049-1062.

11. Zemach A, McDaniel IE, Silva P, Zilberman D: Genome-wide evolutionary analysis of eukaryotic DNA methylation. Science 2010, 328(5980):916-919.

12. Su Z, Han L, Zhao Z: Conservation and divergence of DNA methylation in eukaryotes: new insights from single base-resolution DNA methylomes. Epigenetics 2011, 6(2):134-140.

13. Ramsahoye BH, Biniszkiewicz D, Lyko F, Clark V, Bird AP, Jaenisch R: NonCpG methylation is prevalent in embryonic stem cells and may be mediated by DNA methyltransferase 3a. Proc Natl Acad Sci USA 2000, 97(10):5237-5242.

14. Ichiyanagi T, Ichiyanagi K, Miyake M, Sasaki H: Accumulation and loss of asymmetric non-CpG methylation during male germ-cell development. Nucleic Acids Res 2013, 41(2):738-745.

15. Fulnecek J, Matyasek R, Kovarik A, Bezdek M: Mapping of 5-methylcytosine residues in Nicotiana tabacum $5 \mathrm{~S}$ rRNA genes by genomic sequencing. Mol Gen Genet 1998, 259(2):133-141.

16. Cokus SJ, Feng S, Zhang X, Chen Z, Merriman B, Haudenschild CD, Pradhan $\mathrm{S}$, Nelson SF, Pellegrini M, Jacobsen SE: Shotgun bisulphite sequencing of the Arabidopsis genome reveals DNA methylation patterning. Nature 2008, 452(7184):215-219.

17. Lister R, Ecker JR: Finding the fifth base: Genome-wide sequencing of cytosine methylation. Genome Res 2009, 19(6):959-966.

18. Down TA, Rakyan VK, Turner DJ, Flicek P, Li H, Kulesha E, Graf S, Johnson N, Herrero J, Tomazou EM, et al: A Bayesian deconvolution strategy for immunoprecipitation-based DNA methylome analysis. Nat Biotechnol 2008, 26(7):779-785.

19. Paun O, Bateman RM, Fay MF, Hedren M, Civeyrel L, Chase MW: Stable epigenetic effects impact adaptation in allopolyploid orchids (Dactylorhiza: Orchidaceae). Mol Biol Evol 2010, 27(11):2465-2473.

20. Xu Y, Zhao Q, Mei S, Wang J: Genomic and transcriptomic alterations following hybridisation and genome doubling in trigenomic allohexaploid Brassica carinata x Brassica rapa. Plant biol (Stuttg) 2012, 14(5):734-744

21. Yang C, Zhang M, Niu W, Yang R, Zhang Y, Qiu Z, Sun B, Zhao Z: Analysis of DNA methylation in various swine tissues. PLoS One 2011, 6(1):e16229.

22. Reyna-Lopez GE, Simpson J, Ruiz-Herrera J: Differences in DNA methylation patterns are detectable during the dimorphic transition of fungi by amplification of restriction polymorphisms. Mol Gen Genet 1997, 253(6):703-710.

23. Vos P, Hogers R, Bleeker M, Reijans M, van de Lee T, Hornes M, Frijters A, Pot J, Peleman J, Kuiper M, et al: AFLP: a new technique for DNA fingerprinting. Nucleic Acids Res 1995, 23(21):4407-4414. 
24. Walder RY, Langtimm CJ, Chatterjee R, Walder JA: Cloning of the Mspl modification enzyme. The site of modification and its effects on cleavage by Mspl and Hpall. J Biol Chem 1983, 258(2):1235-1241.

25. Mann MB, Smith HO: Specificity of Hpa II and Hae III DNA methylases. Nucleic Acids Res 1977, 4(12):4211-4221.

26. Roberts RJ, Vincze T, Posfai J, Macelis D: REBASE-a database for DNA restriction and modification: enzymes, genes and genomes. Nucleic Acids Res 2010, 38(Database issue):D234-D236.

27. Lin PM, Lee CH, Roberts RJ: Cloning and characterization of the genes encoding the Mspl restriction modification system. Nucleic Acids Res 1989, 17(8):3001-3011.

28. Card CO, Wilson GG, Weule K, Hasapes J, Kiss A, Roberts RJ: Cloning and characterization of the Hpall methylase gene. Nucleic Acids Res 1990, 18(6):1377-1383.

29. Waalwijk C, Flavell RA: Mspl, an isoschizomer of hpall which cleaves both unmethylated and methylated hpall sites. Nucleic Acids Res 1978, 5(9):3231-3236.

30. Ben-Hattar J, Jiricny J: Effect of cytosine methylation on the cleavage of oligonucleotide duplexes with restriction endonucleases Hpall and Mspl. Nucleic Acids Res 1988, 16(9):4160.

31. Tardy-Planechaud S, Fujimoto J, Lin SS, Sowers LC: Solid phase synthesis and restriction endonuclease cleavage of oligodeoxynucleotides containing 5-(hydroxymethyl)-cytosine. Nucleic Acids Res 1997 25(3):553-559.

32. Korch C, Hagblom P: In-vivo-modified gonococcal plasmid pJD1. A model system for analysis of restriction enzyme sensitivity to DNA modifications. Eur J Biochem 1986, 161(3):519-524.

33. Butkus $V$, Petrauskiene $L$, Maneliene $Z$, Klimasauskas $S$, Laucys $V$, Janulaitis $A$ : Cleavage of methylated CCCGGG sequences containing either N4methylcytosine or 5-methylcytosine with Mspl, Hpall, Smal, Xmal and Cfr9l restriction endonucleases. Nucleic Acids Res 1987, 15(17):7091-7102.

34. Huang LH, Farnet CM, Ehrlich KC, Ehrlich M: Digestion of highly modified bacteriophage DNA by restriction endonucleases. Nucleic Acids Res 1982, 10(5):1579-1591.

35. Brennan CA, Van Cleve MD, Gumport Rl: The effects of base analogue substitutions on the cleavage by the EcoRI restriction endonuclease of octadeoxyribonucleotides containing modified EcoRI recognition sequences. J Biol Chem 1986, 261(16):7270-7278.

36. Jeddeloh JA, Richards EJ: mCCG methylation in angiosperms. Plant J 1996, 9(5):579-586.

37. Fulnecek J, Matyasek R, Kovarik A: Distribution of 5-methylcytosine residues in 5S rRNA genes in Arabidopsis thaliana and Secale cereale. Mol Gen Genomics 2002, 268(4):510-517.

38. Meyer P: DNA methylation systems and targets in plants. FEBS Lett 2011, 585(13):2008-2015.

39. Mathieu O, Reinders J, Caikovski M, Smathajitt C, Paszkowski J: Transgenerational stability of the Arabidopsis epigenome is coordinated by CG methylation. Cell 2007, 130(5):851-862.

40. Sasaki T, Fujimoto R, Kishitani S, Nishio T: Analysis of target sequences of DDM1s in Brassica rapa by MSAP. Plant Cell Rep 2011, 30(1):81-88.

41. Xu M, Li X, Korban SS: DNA-methylation alterations and exchanges during in vitro cellular differentiation in rose (Rosa hybrida L.). Theor Appl Genet 2004, 109(5):899-910.

42. Takamiya T, Hosobuchi S, Asai K, Nakamura E, Tomioka K, Kawase M, Kakutani T, Paterson AH, Murakami Y, Okuizumi H: Restriction landmark genome scanning method using isoschizomers (Mspl/Hpall) for DNA methylation analysis. Electrophoresis 2006, 27(14):2846-2856.

43. Takamiya T, Hosobuchi S, Noguchi T, Asai K, Nakamura E, Habu Y, Paterson $\mathrm{AH}$, lijima $\mathrm{H}$, Murakami $\mathrm{Y}$, Okuizumi $\mathrm{H}$ : Inheritance and alteration of genome methylation in F1 hybrid rice. Electrophoresis 2008, 29(19):4088-4095.

44. Koroma AP, Jones R, Michalak P: Snapshot of DNA methylation changes associated with hybridization in Xenopus. Physiol genomics 2011, 43(22):1276-1280.

45. Xiao J, Song C, Liu S, Tao M, Hu J, Wang J, Liu W, Zeng M, Liu Y: DNA methylation analysis of allotetraploid hybrids of red crucian carp (Carassius auratus red var.) and common carp (Cyprinus carpio L.). PLoS One 2013, 8(2):e56409.

46. Zakrzewski F, Weisshaar B, Fuchs J, Bannack E, Minoche AE, Dohm JC, Himmelbauer H, Schmidt T: Epigenetic profiling of heterochromatic satellite DNA. Chromosoma 2011, 120(4):409-422.
47. You W, Tyczewska A, Spencer M, Daxinger L, Schmid MW, Grossniklaus U, Simon SA, Meyers BC, Matzke AJ, Matzke M: Atypical DNA methylation of genes encoding cysteine-rich peptides in Arabidopsis thaliana. BMC Plant Biol 2012, 12:51.

48. Fulnecek J, Matyasek R, Votruba I, Holy A, Krizova K, Kovarik A: Inhibition of SAH-hydrolase activity during seed germination leads to deregulation of flowering genes and altered flower morphology in tobacco. Mol Genet Genomics 2011, 285(3):225-236.

49. Fojtova M, Kovarik A, Votruba I, Holy A: Evaluation of the impact of Sadenosylhomocysteine metabolic pools on cytosine methylation of the tobacco genome. Eur J Biochem 1998, 252(3):347-352.

doi:10.1186/1471-2156-15-2

Cite this article as: Fulneček and Kovařík: How to interpret Methylation Sensitive Amplified Polymorphism (MSAP) profiles?. BMC Genetics 2014 15:2.

\section{Submit your next manuscript to BioMed Central and take full advantage of:}

- Convenient online submission

- Thorough peer review

- No space constraints or color figure charges

- Immediate publication on acceptance

- Inclusion in PubMed, CAS, Scopus and Google Scholar

- Research which is freely available for redistribution

Submit your manuscript at www.biomedcentral.com/submit
C Biomed Central 